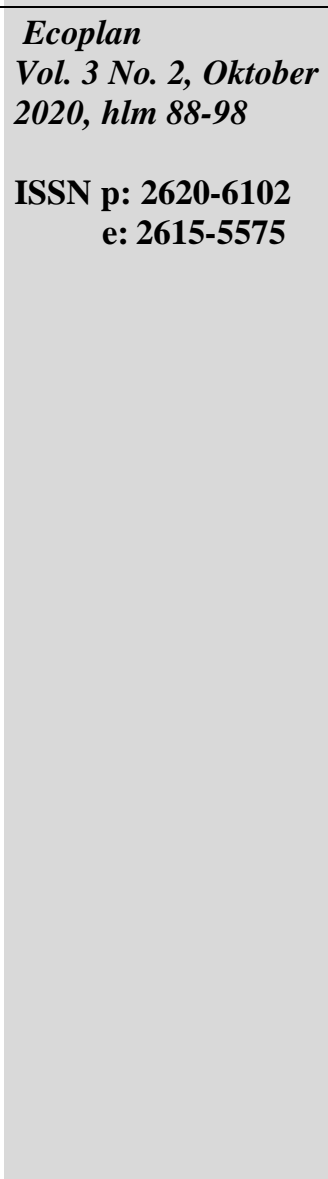

\title{
Sosial Ekonomi Nelayan Pesisir Pantai Desa Swarangan Kecamatan Jorong Kabupaten Tanah Laut
}

\author{
Ika Chandriyanti ${ }^{1}$, Eny Fahrati ${ }^{1)}$
}

Jurusan Ilmu Ekonomi \& Studi Pembangunan, Fakultas Ekonomi dan Bisnis

Universitas Lambung Mangkurat

1) ikachandriyanti.iesp@ulm.ac.id

Abstract-The economic activities of the people on the coast are identical to fishers. Most economic activities are fishing for a lot of fish and processed products (post-harvest marine products). Natural conditions are a factor in the high risk of anglers at sea and are always in economic uncertainty, impacting fishers' income level. This study aims to determine the fishermen community's socio-economic characteristics in Swarangan village, the average income, and to compare the average income per capita with the poverty line. The research method used in this research is a descriptive quantitative method with as many as 62 fishermen samples. The results showed that 1) fishermen's characteristics are still of productive age, have an average junior high school education, and have a side job. 2). The average income from fishing (as fishermen) is mostly below the poverty line. 3) the average total pay of a small proportion of families is below the poverty line. In general, the socio-economic conditions of fishers in Swarangan village are still above the poverty line.

Keywords: fishermen, income, poverty line

\section{Sosial Ekonomi Nelayan Pesisir Pantai Desa Swarangan Kecamatan Jorong Kabupaten Tanah Laut}

Abstrak - Kegiatan ekonomi masyarakat di Pesisir Pantai identik dengan Nelayan. Sebagian besar kegiatan ekonomi adalah penangkapan ikan alut dan olahannya (pasca panen hasil laut). Kondisi alam merupakan salah satu faktor tingginya risiko nelayan di laut dan selalu berada dalam ketidakpastian ekonomi, sehingga berdampak terhadap tingkat pendapatan nelayan. Penelitian ini bertujuan untuk mengetahui karakteristik sosial ekonomi masyarakat Nelayan di desa Swarangan, rata-rata pendapatan, dan membandingkan ratarata pendapatan per kapita dengan Garis Kemiskinan. Metode penelitian yang digunakan dalam penelitian ini adalah metode kuantitatif deskriptif dengan sebanyak 62 nelayan sampel. Hasil penelitian menunjukkan bahwa 1) karakteristik Nelayan adalah masih usia produktif, berpendidikan rata-rata SLTP, dan mempunyai pekerjaan sampingan. 2). rata-rata pendapatan dari hasil Melaut (sebagai Nelayan) sebagian besar berada di bawah Garis Kemiskinan. 3) rata-rata pendapatan total keluarga sebagian kecil berada di bawah Garis Kemiskinan. Secara umum, kondisi social ekonomi nelayan di desa Swarangan masih berada di atas garis kemiskinan.

Kata kunci : Nelayan, Pendapatan, Garis Kemiskinan

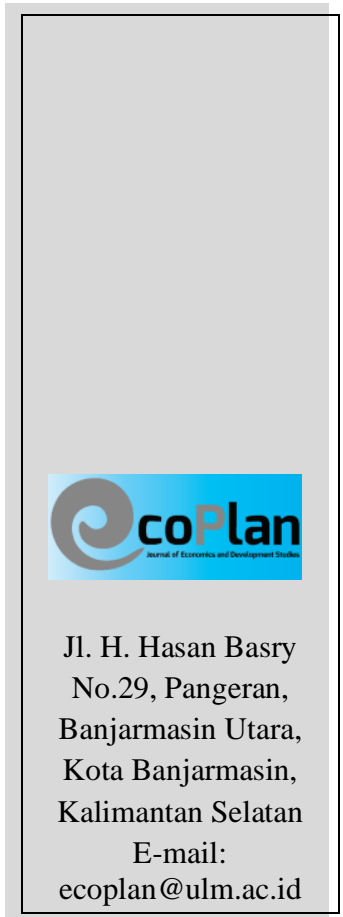




\section{PENDAHULUAN}

Pesisir pantai merupakan salah satu wilayah di Indonesia yang berpotensi untuk berbagai kegiatan sosial ekonomi bagi masyarakat setempat dan merupakan salah satu tempat wisata bagi masyarakat di sekitarnya. Pesisir pantai pada dasarnya identik dengan nelayan.

Kegiatan ekonomi yang utama berhubungan dengan kehidupan penangkapan ikan dan olahannya, sehingga kehidupan petani ikan laut (disebut : Nelayan) tergantung sepenuhnya pada kondisi laut dan isinya. Kondisi alam merupakan faktor utama tingginya risiko nelayan dalam melakukan kegiatannya di laut dan selalu berada di dalam ketidakpastian ekonomi, sehingga akan terdampak terhadap tingkat pendapatan para nelayan.

Pada banyak hasil penelitian di Indonesia, rata-rata pendapatan Nelayan di suatu wilayah belum memberikan tingkat kesejahteraan sesuai dengan yang diharapkan oleh tujuan Negara Indonesia. Menurut Adam (2018), upah riil harian yang diterima seorang buruh tani (termasuk buruh nelayan) hanya sebesar Rp 30.499 perhari. Lebih rendah dibandingkan upah nominal harian seorang buruh bangunan biasa (tukang bukan Mandor), yaitu $\mathrm{Rp} 48.301$ per hari.

Pendidikan, dan keterbatasan akses pemasaran hasil juga merupakan faktor penyebab sebagian besar pendapatan Nelayan berada di bawah garis kemiskinan. Menurut Dahuri (dalam Ferry J. Yulianto dan Aris Munandar, 2016) secara rata-rata $85 \%$ pada tahun 2009 , Nelayan di Indonesia berpendidikan hanya tamat SD dan buta huruf. Kondisi ini akan semakin parah bila tidak ada opportunity cost di wilayah yang bersangkutan.

Salah satu Desa Nelayan di wilayah Kalimantan Selatan adalah desa Swarangan. Desa Swarangan berada di kecamatan Jorong kabupaten Tanah Laut. Desa ini terletak di pesisir pantai dan mata pencaharian utamanya adalah melaut atau Nelayan. Letaknya cukup jauh dari ibukota Kabupaten sehingga akses untuk ke luar Desa juga cukup sulit. Pertumbuhan ekonomi wilayah cenderung lebih lambat dibandingkan dengan kondisi wilayah lain di Kecamatan yang sama.

Beberapa waktu yang lalu di desa ini banyak wisatawan daerah yang datang, bahkan dari kota-kota lain di wilayah Kalimantan Selatan, seperti Banjarmasin, Banjarbaru, dan lain-lain, sehingga memberikan pendapatan tambahan penduduk selain sebagai Nelayan. Akan tetapi dalam kurun waktu beberapa tahun terakhir, di tempat ini sudah tidak ada lagi wisatawan yang datang karena ada tempat wisata pantai lain yang lebih dekat dan lebih mudah dijangkau, sehingga Nelayan tidak banyak lagi yang memperoleh tambahan pendapatan lain. Untuk menambah pendapatan keluarga mereka, masyarakat Nelayan di Desa ini mempunyai pekerjaan sampingan seperti bertani, berdagang, dan beberpa pekerjaan lainnya.

Penelitian tentang sosial ekonomi masyarakat Nelayan di wilayah Desa ini menjadi menarik, karena kajian tentang masyarakat Nelayan tidak banyak dilakukan terutama di wilayah Kalimantan Selatan. Berdasarkan hal tersebut, penelitian ini bertujuan untuk mengetahui karakteristik sosial ekonomi masyarakat Nelayan di desa Swarangan, menghitung rata-rata pendapatan mereka dan membandingkan rata-rata pendapatan per kapita mereka dengan Garis Kemiskinan.

\section{TINJAUAN PUSTAKA}

\section{Nelayan}

Menurut UU Nomor 7 tahun 2016 tentang Perlindungan dan Pemberdayaan Nelayan, Pembudi Daya Ikan, dan Petambak Garam :

1. Nelayan adalah setiap orang yang mata pencahariannya melakukan penangkapan ikan.

2. Nelayan Tradisional adalah Nelayan yang melakukan Penangkapan Ikan di perairan yang merupakan hak Perikanan tradisional yang telah dimanfaatkan secara turuntemurun sesuai dengan budaya dan kearifan lokal.

Menurut Subri (2005) dalam Yuliriane (2012) nelayan dikelompokkan dalam 3 kategori, antara lain:

1. Nelayan Buruh, yaitu nelayan yang bekerja dengan alat tangkap milik orang lain.

2. Nelayan Juragan, yaitu nelayan yang memiliki alat tangkap dan dioperasikan oleh orang lain.

3. Nelayan Perorangan, yaitu nelayan yang memiliki peralatan tangkap sendiri dan dalam pengoperasiannya tidak melibatkan orang lain.

Berdasarkan hal tersebut di atas, maka Nelayan di desa Swarangan pada dasarnya sama saja dengan Nelayan di wilayah lain di Indonesia, berskala kecil dan masih bersifat tradisional.

\section{Pendapatan}

Konsep atau definisi tentang pendapatan dan pendapatan nasional sangat banyak ditemukan. Berbicara tentang pendapatan nasional, maka yang dibicaarkan adalah 
pendapatan dalam suatu negara secara makro, sedangkan pendapatan adalah membahas pendapatan dari sisi mikro, yaitu dalam suatu usaha atau perorangan.

Pendapatan adalah pendapatan uang yang diterima dan diberikan kepada subjek ekonomi berdasarkan prestasi-prestasi yang diserahkan yaitu berupa pendapatan dari profesi yang dilakukan sendiri atau usaha perorangan dan pendapatan dari kekayaan. Besarnya pendapatan seseorang bergantung pada jenis pekerjaannya. Selain itu, Sukirno juga mendefinisikan pendapatan adalah jumlah penghasilan yang diterima oleh penduduk atas prestasi kerjanya selama satu periode tertentu, baik harian, mingguan, bulanan, ataupun tahunan. (Sukirno, 2006).

Pendapatan atau income adalah uang yang diterima oleh seseorang dan perusahaan dalam bentuk gaji, upah, sewa bunga, dan laba termasuk juga beragam tunjangan, seperti kesehatan dan pensiun. (Soediyono, 2009)

Menurut pakar ekonomi Indonesia yang paling senior, Soemitro Djojohadikusumo (dalam Hestanto, 2018) pendapatan merupakan jumlah barang dan jasa yang memenuhi tingkat hidup masyarakat, dimana dengan adanya pendapatan yang dimiliki oleh setiap jiwa disebut dengan pendapatan perkapita dimana pendapatan perkapita menjadi tolok ukur kemajuan atau perkembangan ekonomi.

Pendapatan keluarga merupakan balas karya atau jasa atau imbalan yang diperoleh karena sumbangan yang diberikan dalam kegiatan produksi. Secara konkritnya pendapatan keluarga berasal dari :

1.Usaha itu sendiri : misalnya berdagang, bertani, membuka usaha sebagai wiraswastawan.

2. Bekerja pada orang lain: misalnya sebagai pegawai negeri atau karyawan

3. Hasil dari pemilihan: misalnya tanah yang disewakan dan lain-lain. Pendapatan bisa berupa uang maupun barang misal berupa santunan baik berupa beras, fasilitas perumahan dan lain-lain. Pada umumnya pendapatan manusia terdiri dari pendapatan nominal berupa uang dan pendapatan riil berupa barang. (Gilarso, 2008)

\section{Kemiskinan dan Garis Kemiskinan}

Kemiskinan merupakan istilah yang sering muncul dalam berbagai tulisan dan penelitian ilmiah. Kemiskinan merupakan kondisi yang selalu menjadi pemikiran pakar dan Pemerintah suatu negara, termasuk di Indonesia, karena dampaknya yang sangat luas terhadap sosial ekonomi negara yang bersangkutan. Berbagai teori dijadikan dasar untuk mendukung kebijakan penanggulangan kemiskinan, dan tentu saja data yang tepat dan akurat adalah dasar utama untuk kebijakan yang dikeluarkan.

Ada dua sisi kemiskinan yang menjadi ukuran, yaitu kemiskinan absolut dan kemiskinan relatif. (Tri Wahyu R, 2009)

1. Kemiskinan relatif merupakan kondisi miskin karena pengaruh kebijakan pembangunan yang belum mampu menjangkau seluruh lapisan masyarakat sehingga menyebabkan ketimpangan distribusi pendapatan. Standar minimum disusun berdasarkan kondisi hidup suatu negara pada waktu tertentu dan perhatian terfokus pada golongan penduduk "termiskin" misalnya 20 persen atau 40 persen lapisan terendah dari total penduduk yang telah diurutkan menurut pendapatan/ pengeluarannya. Kelompok ini merupakan penduduk relatif miskin. Dengan demikian, ukuran kemiskinan relatif sangat tergantung pada distribusi pendapatan/pengeluaran penduduk.

2. Kemiskinan Absolut Kemiskinan secara absolut ditentukan berdasarkan ketidakmampuan untuk mencukupi kebutuhan pokok minimum seperti pangan, sandang, kesehatan, perumahan dan pendidikan yang diperlukan untuk bisa hidup dan bekerja. Kebutuhan pokok minimum diterjemahkan sebagai ukuran finansial dalam bentuk uang. Nilai kebutuhan minimum, kebutuhan dasar tersebut dikenal dengan istilah garis kemiskinan. Penduduk yang pendapatannya di bawah garis kemiskinan digolongkan sebagai penduduk miskin. Garis kemiskinan absolut "tetap (tidak berubah)" dalam hal standar hidup. Garis kemiskinan absolut mampu membandingkan kemiskinan secara umum. Menurut, Menurut BPS (2018), Garis Kemiskinan merupakan batas minimum pendapatan yang harus dipenuhi untuk memperoleh standar hidup, baik untuk kebutuhan makanan dan nonmakanan di suatu wilayah. Jika di bawah angka tersebut maka masuk kategori penduduk miskin.

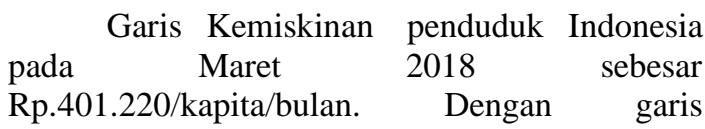
kemiskinan tersebut, maingkat kemiskinan di Indonesia pada tahun 2018 akhirnya dapat menembus di bawah satu digit, yaitu 9,82 persen pada bulan Maret dan terus menurun menjadi 9,66 persen pada bulan September yang lalu. Penurunan angka kemiskinan tersebut terjadi di hampir seluruh provinsi. Namun sebaliknya di beberapa provinsi mengalami kenaikan 
kemiskinan dari tahun sebelumnya, yaitu di Provinsi Kepulauan Riau, Kepulauan Bangka Belitung, NTT, Maluku Utara, dan Papua. Bahkan, di beberapa povinsi seperti NTT dan Papua, kemiskinan tidak mengalami penurunan dari beberapa tahun sebelumnya. (Kedeputian Kependudukan dan Ketenagakerjaan, Bappenas, 2018).

Pada tahun 2019, Garis Kemiskinan Indonesia meningkat menjadi Rp 425.250 per kapita per bulan. (BPS, 2019). Kenaikan yang ditetapkan oleh Pemerintah disebabkan kenaikan inflasi dan bertambahnya kebutuhan penduduk di sektor primer, sekunder, maupun tersier. Walaupun terjadi kenaikan nilai garis kemiskinan, secara persentase terjadi penurunan jumlah kemiskinan di Indonesia sebesar 0,25\% dari bulan Maret 2019 dibandingkan bulan September 2019. (BPS,2019).

\section{METODE PENELITIAN}

Penelitian yang melingkupi karakteristik dan pendapatan Nelayan di wilayah desa Swarangan kecamatan Jorong Kabupaten Tanah Laut. Penelitian ini menggunakan metode penelitian kualitatif deskriptif. Penelitian kuantitatif deskriptif digunakan untuk menggambarkan,menjelaskan, atau meringkaskan berbagai kondisi, situasi, fenomena,atau berbagai variabel penelitian menurut kejadian sebagaimana adanya yang dapat dipotret, diwawancara, diobservasi, serta yang dapat diungkapkan melalui bahan-bahan dokumenter.(Burhan Bungin, 2005)

Data dalam penelitian ini terutama sekali adalah data primer yang diperoleh dari masyarakat Nelayan di wilayah penelitian. Data sekunder, sebagai data pendukung, diperoleh dari Kantor Desa Swarangan dan wawancara dengan Kepala Desa, serta dari Kantor Kecamatan Jorong.

Populasi dalam penelitian ini adalah seluruh masyarakat yang pekerjaan utamanya adalah sebagai Nelayan dan merupakan populasi yang homogen. Populasi ini menjadi homogen, karena karakteristik mereka sama dan penggunaan peralatan tangkap dan kapal yang mereka gunakan mempunyai standar yang sama, yaitu masih trasidional dan tidak menggunakankapal dengan skala kemampuan yang bereda. Jumlah Nelayan tersebut sebanyak 158 orang.

Sampel dipilih secara acak/random, dengan menggunakan rumus Slovin sebagai berikut:

$$
n=\frac{N}{1+N e}=\frac{158}{1+(158)(0,1)^{2}}=62
$$

Di mana:

$\mathrm{n}=$ Jumlah sampel yang diambil

$\mathrm{N}=$ Jumlah anggota populasi

$\mathrm{e}=$ Taraf nyata, $10 \%$

(Hasyim Ali Imran, 2017)

Berdasarkan perhitungan tersebut, jumlah sampel dalam penelitian ini adalah 62 orang Nelayan.

Pendapatan Nelayan sampel adalah:

1. Pendapatan utama didefinisikan sebagai pendapatan yang diperoleh Nelayan sampel selama Melaut, dan dinyatakan dalam ribuan rupiah.

2. Pendapatan sampingan didefinisikan sebagai pendapatan yang diperoleh Nelayan sampel dari pekerjaannya selain Melaut, dan dinyatakan dalam ribuan rupiah.

3. Pendapatan keluarga didefinisikan sebagai pendapatan yang diperoleh Nelayan sampel selama Melaut ditambah pendapatan dari pekerjaan selain Melaut serta ditambah pendapatan dari anggota keluarga lain (isteri atau anak), dan dinyatakan dalam ribuan rupiah.

Data yang diperoleh disusun dengan tabel-tabel dan dianalisis secara deskriptif dengan menggunakan tabulasi silang.

\section{HASIL DAN PEMBAHASAN \\ Karakteristik Responden \\ Usia Responden}

Menurut BPS tahun 2018, usia produktif tenagakerja adalah 15-64 tahun yang terbagi atas mereka yang bekerja atau mereka yang tidak bekerja (sekolah atau sudah pensiun). Berdasarkan kriteria dari BPS tersebut, maka Responden yang diteliti semuanya termasuk ke dalam usia produktif.

Tabel 1. Usia Responden

\begin{tabular}{ccr}
$\begin{array}{c}\text { Usia } \\
\text { (Tahun) }\end{array}$ & $\begin{array}{c}\text { Jumlah } \\
\text { Responden } \\
\text { (Orang) }\end{array}$ & $\begin{array}{r}\text { Persen } \\
(\boldsymbol{\%})\end{array}$ \\
\hline $19-28$ & 6 & 9,68 \\
$29-38$ & 20 & 32,26 \\
$39-48$ & 21 & 33,87 \\
$49-58$ & 9 & 14,52 \\
$59-68$ & 6 & 9,68 \\
\hline J u m l a h & $\mathbf{6 2}$ & $\mathbf{1 0 0 , 0 0}$ \\
\hline
\end{tabular}

Sumber: Hasil Survey

Tabel 1 tersebut memberikan gambaran bahwa Nelayan di wilayah Swarangan adalah mereka yang bekerja sesuai dengan usia tenaga kerja yang layak untuk bekerja, artinya tidak 
berada pada usia sekolah. Mereka yang bekerja di sektor ini, paling banyak berusia antara 29 tahun sampai 48 tahun, yaitu sebanyak $66,13 \%$. Angka ini mempunyai pengertian bahwa lebih dari 66,13\% Nelayan di Desa ini masih dalam usia produktif dan masih mampu memperoleh pendapatan dari sektor ini.

Responden yang berusia $19-28$ berjumlah $9,68 \%$, yang berarti bahwa mereka yang masih muda belum banyak yang bekerja di bidang ini atau mereka memilih pekerjaan lain di luar sebagai Nelayan. Reponden yang berusia 59 - 68 tahun mempunyai jumlah yang sama dengan responden yang berusia $19-28$ tahun, yaitu sebanyak 9,68 \%. Hal ini memberikan gambaran, bahwa di wilayah ini, Nelayan yang sudah berusia lebih dari 50 tahun mulai mengurangi kegiatannya untuk bekerja dengan berbagai alasan, seperti kesehatan dan sudah ada yang menanggung hidup mereka.

\section{Pendidikan Responden}

Rata-rata pendidikan Responden adalah SLTP. Hal ini menunjukkan bahwa Nelayan di desa Swarangan mempunyai pendidikan yang cukup memadai, sehingga mampu memberikan inovasi dalam pekerjaan mereka. Tabel di bawah ini memberikan hasil survey di wilayah penelitian.

Tabel 2. Pendidikan Responden

\begin{tabular}{lcr}
\hline Pendidikan & $\begin{array}{c}\text { Jumlah } \\
\text { Responden } \\
\text { (Orang) }\end{array}$ & $\begin{array}{c}\text { Persen } \\
(\mathbf{\%})\end{array}$ \\
\hline Tidak Sekolah & 5 & 8,06 \\
SD & 6 & 9,68 \\
SLTP & 51 & 82,26 \\
\hline Jumlah & $\mathbf{6 2}$ & $\mathbf{1 0 0 , 0 0}$ \\
\hline
\end{tabular}

Sumber : Hasil Survey

Dari tabel tersebut, terlihat bahwa sebanyak 83,36 \% Nelayan berpendidikan SLTP. Mereka yang hanya sekolah SD dan tidak sempat mengenyam pendidikan, mereka bekerja berdasarkan pengalaman turun temurun dari orang tua mereka. Berdasarkan tabel tersebut juga, terlihat tidak ada Responden yang berpendidikan SLTP ke atas. Artinya, penduduk yang bekerja sebagai Nelayan adalah mereka yang bependidikan tertinggi hanya sampai SLTP. Pendudk yang berpendidikan SLTP ke atas tidak bekerja sebagai Nelayan, ada yang bekerja sebagai perangkat desa, pedagang, dan pegawai pemerintahan dan pegawai swasta di luar Desa.

\section{Pekerjaan Sampingan}

Selain sebagai Nelayan, sebagian responden mempunyai pekerjaan sampingan.
Pada Tabel 3. berikut ini berisi data tentang pekerjaan sampingan Responden.

Tabel 3. Pekerjaan Sampingan Responden

\begin{tabular}{|c|c|c|}
\hline Pekerjaan & $\begin{array}{l}\text { Jumlah } \\
\text { Reponden } \\
\text { (Orang) }\end{array}$ & $\begin{array}{c}\text { Persen } \\
(\%)\end{array}$ \\
\hline 1. Buruh Sawit & 14 & 22,58 \\
\hline 2. Petani & 24 & 38,71 \\
\hline 3. Membuat Atap & 2 & 3,23 \\
\hline 4. Petani dan Buruh & & \\
\hline Sawit & 3 & 4,84 \\
\hline 5. Buruh Sawit dan & & \\
\hline Membuat Atap & 1 & 1,61 \\
\hline 6. Petani dan Membuat & & \\
\hline Atap & 2 & 3,23 \\
\hline 7. Berdagang & 1 & 1,61 \\
\hline 8. Tidak Ada Pekerjaan & & \\
\hline Sampingan & 15 & 24,49 \\
\hline Jumlah & 62 & 100,00 \\
\hline
\end{tabular}

Sekitar 75\% Responden mempunyai pekerjaan sampingan yang dilakukan pada saat tidak ke laut. Pekerjaan ini bertujuan untuk menambah pendapatan mereka. Dari pekerjaa sampingan, mereka menyatakan dapat menambah pendapatan rumah tangga.

Walaupun desa Swarangan merupakan wilayah laut, ternyata pekerjaan sampingan mereka adalah di sektor Pertanian, pekerjaan sebagai Petani dan Buruh Sawit. Kedua pekerjaan ini dapat ditinggalkan ketika melaut. Pertanian mereka adalah pertanian tanaman pangan (padi dan palawija), sedangkan sebagai Buruh Sawit, mereka hanya sebagai pekerja per hari (buruh harian) atau setiap mereka hadir bekerja.

Walaupun demikian, banyak juga masyarakat yang tidak mempunyai pekerjaan sampingan selain sebagai Nelayan. Alasan mereka adalah karena sering waktu ke laut lama dan merasa lelah setelah pulang melaut. Ada juga alasannya karena tidak mendapatkan pekerjaan tersebut, dan alasan lain karena pendapatan dari melaut sudah cukup untuk biaya rumah tangga.

\section{Pekerjaan Isteri}

Sebagian besar isteri Nelayan juga bekerja untuk membantu biaya rumah tangga. Jumlah pekerjaan isteri Nelayan yang paling banyak adalah sebagai Petani dan Berdagang, yaitu masing-masing sebanyak 16 orang $(25,81 \%)$. Kondisi ini dapat dilihat pada Tabel 4. 
Tabel 4. Pekerjaan Isteri Petani

\begin{tabular}{llc}
\hline \multicolumn{1}{c}{ Pekerjaan } & $\begin{array}{c}\text { Jumlah } \\
\text { Reponden } \\
\text { (Orang) }\end{array}$ & $\begin{array}{c}\text { Persen } \\
(\mathbf{\%})\end{array}$ \\
\hline 1. Petani & 24 & 38,71 \\
2. Membuat Atap & 2 & 3,23 \\
3. Buruh Menjemur Ikan & 3 & 4,84 \\
4. Petani dan Membuat & & \\
$\quad$ Atap & 2 & 3,23 \\
5. Berdagang & 1 & 1,61 \\
6. Tidak Ada Pekerjaan & & \\
Sampingan & 15 & 24,49 \\
\hline \multicolumn{1}{c}{ Jumlah } & $\mathbf{6 2}$ & $\mathbf{1 0 0 , 0 0}$ \\
\hline
\end{tabular}

Sumber: Data Hasil Survey

Berbagai alasan diberikan oleh Responden, tentang pekerjaan isteri mereka. Ada yang menyatakan, bahwa mereka bekerja untuk mengisi waktu luang. Alasan lain adalah untukmenambah pendapatan rumah tangga.

Berdagang bagi mereka adalah pekerjaan isteri yang paling mudah dan dapat dikerjakan didepan rumah mereka, yaitu untuk mereka yang berdagang peralatan rumah tangga dan jajanan anak. Selain itu, ada juga yang berdagang di pasar lokal. Pekerjaan isteri Nelayan lain hampir sama dengan pekerjaan sampingan Nelayan, karena hanya itu pekerjaan yang ada di desa Swarangan tersebut.

Alasan isteri Nelayan yang tidak bekerja, antara lain adalah mempunyai anak kecil dan untuk biaya rumah tangga sudah cukup dari pendapatan suami. Alasan lain, tidak ingin meninggalkan rumah jika bekerja jauh dari tempat tinggal.

\section{Jumlah Tanggungan Keluarga}

Jumlah keluarga yang ditanggung bukan hanya anak dan isteri, tapi ada juga yang menangung orang tua dan keponakan. Walaupun demikian, tidak banyak Responden yang menanggung keluarga selain anak dan isteri. Tabel berikut memberikan gambaran jumlah keluarga yang ditanggung Responden.

Tabel 5. Jumlah Tanggung Keluarga Responden

\begin{tabular}{|c|c|c|}
\hline Jumlah Tanggungan & $\begin{array}{c}\text { Jumlah } \\
\text { Reponden } \\
\text { (Orang) }\end{array}$ & $\begin{array}{c}\text { Persen } \\
(\%)\end{array}$ \\
\hline 1. Tidak Ada & 4 & 6,45 \\
\hline 2. Satu & 8 & 12,39 \\
\hline 3. Dua & 11 & 17,74 \\
\hline 4. Tiga & 33 & 53,23 \\
\hline 5. Empat & 6 & 9,68 \\
\hline Jumlah & 62 & 100,00 \\
\hline
\end{tabular}

Paling banyak Responden memiliki tanggungan 3 (tiga) orang, yaitu sebanyak $53,23 \%$. Tanggungan mereka ini adalah seorang isteri dan 2 (dua) anak, tapi ada juga Responden yang tanggungannya adalah seorang isteri, seorang anak, dan seorang Ibu.

Tanggungan keluarga ini, bukan hanya tinggal di rumah, tetapi juga diberikan juga biaya untuk hidup, yaitu termasuk biaya sandang pangan keluarga. Walaupun demikian, tidak ada keluhan bagi Nelayan tentang tanggungan keluarga, termasuk menanggung bukan keluarga inti. Alasan mereka, dengan menanggung keluarga lain selain anak dan isteri akan menambah rezeki dan dapat membantu pekerjaan rumah tangga, bahkan Responden yang menanggung keponakan laki-laki dapat membantu mereka melaut.

Mereka yang tanggungan keluarga, selain isteri, adalah anak-anak. Anak-anak Nelayan di wilayah ini, sebagian besar masih bersekolah. Di wilayah ini tidak ada sekolah selain Sekolah Dasar. Anak-anak Nelayan bersekolah ke luar wilayah Desa, yaitu ke Kecamatan Jorong, bahkan ada yang bersekolah ke Kota Pelaihari.

Berdasarkan pembahasan dan dari tabeltabel di atas, secara umum karakteristik Nelayan di desa Swarangan kecamatan Jorong adalah :

1. Usia mereka masih dalam usia produktif, sehingga masih mampu bekerja sampai beberapa tahun ke depan dan menghasilkan pendapatan yang layak untuk keluarga.

2. Pendidikan rata-rata Nelayan adalah tingkat SLTP. Kondisi ini disebabkan sekolah yang terdekat dari desa mereka adalah hanya SLTP Negeri di Jorong. Selain itu, pekerjaan sebagai nelayan adalah pekerjaan turun termurun, sehingga orang tua mereka tidak mementingkan sekolah dan lebih penting membantu pekerjaan orang tua.

3. Selain sebagai Nelayan, penduduk Desa ini juga mempunyai pekerjaan sampingan, antara lain sebagai Petani (terbanyak), baik sebagai buruh tani maupun mempunyai lahan pertanian sendiri. Pertanian yang ada di wilayah tersebut adalah sawah, sayursayuran, dan beternak sapi. Pekerjaan sampingan lain adalah sebagai pekerjaan di perkebunan kelapa sawit di Pelaihari, ikut bekerja sebagai pembuat atap, dan berdagang.pekerjaan sampingan dilakukan pada saat mereka tidak ke laut, terutama pada musim-musim angin kencang. Kendatipun banyak Nelayan yang mempunyai pekerjaan sampingan, ada juga mereka yang hanya bekerja sebagai Nelayan saja dengan berbagai 
alasan, antara lain pendapatan mencukupi dan kesehatan yang tidak memungkinkan.

4. Isteri para Nelayan di Desa ini sebagian juga bekerja untuk membantu pendapatan keluarga dan untuk mengisi waktu luang mereka. Pekerjaan yang ditekuni sama dengan pekerjaan sampingan suami mereka, yaitu sebagai Petani, ikut bekerja di perkebunan kelapa sawit, berdagang, dan membuat atap.

5. Sebagai kepala keluarga, Nelayan di wilayah ini mempunyai tanggungan keluarga.. Jumlah tanggungan ini ber variasi, antara 2 (dua) orang sampai 4 (empat) orang, tetapi yang terbanyak adalah menanggung 3 (tiga) orang karena rata-rata Nelayan mempunyai 2 (dua) orang anak dan pada umumnya masih sekolah.

6. Secara umum, perbedaan karakteristik Nelayan di wilayah ini dengan Nelayan wilayah-wilayah lainnya di Indonesia adalah lah adanya pekerjaan sampingan Nelayan selain hanya sebagai Nelayan. Selama menunggu musim atau tidak melaut, mereka akan bekerja sebagai Petani, buruh sawit, dan beberapa pekerjaan lain. Dengan demikian, mereka mempunyai tambahan pendapatan selain dari pendapatan utama mereka sebagai Nelayan.

\section{Pendapatan Nelayan}

Pendapatan Responden dihitung berdasarkan dari pendapatan Nelayan sampel. Sampel yang diperoleh dengan perhitungan dapat menggambarkan kondisi anggota populasi, dengan kata lain, perhitungan pendapatan Responden sebagai sampel dapat memberikan gambaran secara umum tentang pendapatan Nelayan di desa Swarangan.

\section{Frekuensi Nelayan Melaut}

Pendapatan rata-rata nelayan dari hasil laut adalah pendapatan kotor yang diterima dari hasil penjualan tangkapan. Jenis tangkapan, antara lain ikan peda, udang, kepiting, dan jenis ikan lainnya. Harga jualnya juga bervariasi sesuai jenis tangkapan. Selain itu, setiap nelayan berbeda hasil tangkapannya per bulan tergantung berapa kali mereka turun ke laut dan setiap kali melaut juga berbeda rata-rata hasil yang diperoleh.
Tabel 6. Frekuensi Responden Melaut

\begin{tabular}{ccc}
\hline $\begin{array}{c}\text { Frekuensi } \\
\text { (Kali) }\end{array}$ & $\begin{array}{c}\text { Jumlah } \\
\text { Reponden } \\
\text { (Orang) }\end{array}$ & $\begin{array}{c}\text { Persen } \\
(\boldsymbol{\%})\end{array}$ \\
\hline $1-3$ & 16 & 25,81 \\
$4-6$ & 37 & 59,68 \\
$>6$ & 9 & 14,52 \\
\hline Jumlah & $\mathbf{6 2}$ & $\mathbf{1 0 0 , 0 0}$ \\
\hline
\end{tabular}

Sumber : Data Hasil Survey

Hasil survey di lapangan, rata-rata nelayan melaut atau turun ke laut sebanyak 4 (empat) sampai 5 (lima) kali dalam sebulan. Semakin sering mereka ke laut semakin sedikit waktu mereka berada disana, sehingga ikan yang dihasilkan seringkali lebih sedikit dibandingkan mereka yang tidak sering ke laut tetapi berada di laut lebih lama.

Lama nelayan sekali turun melaut adalah 5 (lima) jam sampai 48 jam. Artinya, ada yang turun ke laut hanya 5 (lima) jam, tetapi ada yang sampai 48 jam. Mereka yang lebih pendek jam turun ke laut biasanya dalam sebulan akan melaut antara 5 (lima) sampai 7 (tujuh) kali, tetapi yang berangkat ke laut dengan waktu yang lama (sampai 48 jam), mereka hanya melaut sebanyak 2 (dua) kali sebulan.

Berbagai alasan yang dikemukakan nelayan tentang frekuensi mereka ke laut. Mereka yang waktu melautnya lebih pendek karena kapal mereka kecil dan tidak bisa terlalu lama di laut dan hasil tangkapan mereka juga cepat didapat, yaitu jenis ikan yang tidak terlalu besar, seperti peda atau cumi. Nelayan yang waktu melautnya lebih lama, menggunakan kapal yang lebih besar, sehingga bisa bertahan lama di laut dan bisa memperoleh ikan-ikan yang lebih besar.

\section{Pendapatan Dari Hasil Laut (Pendapatan Utama)}

Sesuai dengan Sadono Sukirno (2006), pendapatan Nelayan di wilayah ini diperoleh dari hasil melaut, dan secara umum adalah pendapatan perorangan dalam satu periode, yaitu dalam satu bulan.

Pendapatan dari hasil laut adalah pendapatan yang diperoleh dari penjualan hasil tangkapan ikan di laut dikurangi dengan biayabiaya yang dikeluarkan pada saat melaut. Biayabiaya yang dikeluarkan adalah biaya bahan bakar, konsumsi, dan lain-lain. Besarnya biaya tergantung dari lamanya dan seringnya waktu ke laut. Besar kecilnya biaya yang dikeluarkan tentu saja akan berpengaruh terhadap pendapatan bersih nelayan. Oleh karena itu, nelayan akan berusaha menekan biaya sekecil mungkin untuk memperoleh pendapatan bersih yang lebih besar.

Pendapatan kotor nelayan berkisar antara Rp 1.400.000 sampai lebih dari Rp 25.000.000 
per bulan, tergantung dari berapa kali dan berapa lama turun ke laut serta berapa banyak hasilyang diperoleh dan berapa jumlah yang dijual. Semua nelayan responden menyatakan, bahwa hasil laut semuanya langsung dijual karena tidak ada

\begin{tabular}{lcc}
\hline \multicolumn{1}{c}{$\begin{array}{c}\text { Pendapatan } \\
\text { (Rp.) }\end{array}$} & $\begin{array}{c}\text { Jumlah } \\
\text { Reponden } \\
\text { (Orang) }\end{array}$ & \multicolumn{1}{c}{$\begin{array}{c}\text { Persen } \\
(\%)\end{array}$} \\
\hline 1. $\begin{array}{l}1.400 .000- \\
5.374 .999\end{array}$ & 43 & 69,35 \\
2. $\begin{array}{l}5.375 .000- \\
9.349 .999\end{array}$ & 7 & 22,29 \\
3. $\begin{array}{l}9.350 .000- \\
13.324 .999\end{array}$ & 6 & 9,68 \\
4. $\begin{array}{l}13.325 .000- \\
17.299 .999\end{array}$ & 1 & 1,61 \\
5. $\begin{array}{l}17.300 .000- \\
21.274 .999\end{array}$ & 4 & 6,45 \\
6. $\begin{array}{l}21.275 .000- \\
25.249 .999\end{array}$ & 1 & 1,61 \\
\hline Jumlah & $\mathbf{6 2}$ & $\mathbf{1 0 0 , 0 0}$ \\
\hline Sumber : Hasil Survey & &
\end{tabular}

Dari hasil survey, ternyata sebagian besar nelayan mempunyai pendapatan kotor kurang dari Rp 5.375.000 per bulan, yaitu sebanyak $69,35 \%$ nelayan. Hal ini berhubungan dengan frekuensi nelayan ke laut yang rata-rata hanya 4 (empat) sampai 5 (lima) kali dan rata-rata hanya 5 (lima) sampai 6 (enam) jam saja berada di laut. Hanya beberapa nelayan yang belaut dengan waktu yang lama dan memperoleh hasil yang lebih banyak sehingga pendapatan bersih mereka juga lebih banyak.

Selain itu, hasil tangkapan yang diperoleh juga dipengaruhi oleh lamanya waktu. Waktu yang lama dan panjang akan memperoleh tangkapan yang banyak dan jenis tangkapan yang bernilai ekonomis lebih besar, seperti udang besar, ikan tenggiri, dan lain-lain. Biasanya hasil laut ini berada di tempat yang lebih dalam dan lebih jauh dari pantai, sehingga memerlukan waktu yang lebih lama serta memerlukan kapal yang lebih besar. Rata-rata kapal yang dimiliki nelayan adalah kapal kecil yang tidak dapat melaut lebih lama dan lebih jauh, sehingga mempengaruhi jumlah dan jenis tangkapan dan pada gilirannya mempengaruhi pendapatan nelayan.

Pendapatan bersih nelayan dipengaruhi oleh biaya-biaya operasonal yang dikeluarkan selama melaksana kan kegiatan mencari ikan dilaut, karena pendapatan bersih adalah pendapatan dari melaut dikurangi dengan biayabiaya operasional sellama melaut. Semakin lama melaut, maka biaya yang dikeluarkan akan semakin besar. Biaya yang dikeluarkan nelayan antara Rp 174.000 sampai Rp 4.980.000, penyimpanan yang memadai. Tabel 7 adalah data tentang pendapatan responden dari hasil melaut.

Tabel 7. Pendapatan Utama Responden tergantung dari frekuensi ke laut dan lamanya di laut. Tabel 8 di bawah ini adalah pendapatan bersih nelayan responden.

Tabel 8. Pendapatan Bersih Responden Dari Melaut

\begin{tabular}{|c|c|c|c|}
\hline & $\begin{array}{c}\text { Pendapatan } \\
\text { (Rp.) }\end{array}$ & $\begin{array}{c}\text { Jumlah } \\
\text { Reponden } \\
\text { (Orang) }\end{array}$ & $\begin{array}{c}\text { Persen } \\
(\%)\end{array}$ \\
\hline 1. & $<50.000$ & 5 & 8,06 \\
\hline 2. & $\begin{array}{l}50.000- \\
2.200 .000\end{array}$ & 28 & 45,16 \\
\hline 3. & $\begin{array}{l}2.250 .000- \\
4.400 .000\end{array}$ & 14 & 22,58 \\
\hline 4. & $\begin{array}{l}4.450 .000- \\
6.600 .000\end{array}$ & 4 & 6,45 \\
\hline 5. & $\begin{array}{l}6.650 .000- \\
8.800 .000\end{array}$ & 1 & 1,61 \\
\hline & $\begin{array}{l}8.850 .000- \\
11.000 .000\end{array}$ & 1 & 1,61 \\
\hline & $>11.000 .000$ & 9 & 14,52 \\
\hline $\mathbf{J u}$ & mlah & 62 & 100,00 \\
\hline
\end{tabular}

Sumber : Hasil Survey

Dibandingkan dengan Tabel 7, maka pada Tabel 8 terlihat pendapatan bersih sebagian nelayan tidak terlalu besar. Hal ini disebabkan biaya operasional mereka cukup besar, sehingga lebih banyak mengurangi pendapatan mereka dari hasil penjualan hasil tangkapan. Selain itu, frekuensi nelayan berada di laut juga mempengaruhi fluktuasi pendapatan nelayan, sehingga ada 14,62 \% nelayan mempunyai pendapatan bersih per bulan yang besar, yaitu lebih dari Rp 11.000.000, bahkan sampai Rp 25.000.000 per bulan. Namun secara rata-rata pendapatan bersih nelayan hanya $\mathrm{Rp} 4.245 .984$ per bulan.

\section{Pendapatan Total Keluarga}

Perbedaan pendapatan bersih yang sangat besar antara pendapatan tertinggi dengan pendapatan terendah, karena perbedaan frekuensi dan lama melaut, perbedaan kapal, dan perbedan hasil dan jenis tangkapan. Nelayan di wilayah ini sangat memahami kondisi tersebut, tetapi mereka tidak mempunyai kemampuan yang memadai untuk meningkatkan pendapatan dari melaut tersebut. Oleh karena itu, sebagian nelayan mempunyai pekerjaan sampingan dan isteri mereka juga bekerja. Dengan adanya pekerjaan 
sampingan dan pekerjaan isteri akan membantu menambah pendapatan rumah tangga.

Pendapatan nelayan setelah ada tambahan pendapatan sampingan dan pendapatan isteri adalah antara Rp 100.000 sampai Rp 30.000.000 per bulan, bahkan ada yang pendapatan mereka lebih kecil dibandingkan biaya operasional melaut. Walaupun demikian, secara rata-rata tingkat pendapatan keluarga nelayan di wilayah ini cukup tinggi, yaitu Rp 6.762.919 per bulan. Pendapatan keluarga nelayan setelah digabungkan dengan pendapatan sampingan nelayan dan pendapatan isteri dapat dilihat pada Tabel 9 berikut ini.

Tabel 9. Pendapatan Total Keluarga Responden

\begin{tabular}{|c|c|c|}
\hline $\begin{array}{c}\text { Pendapatan } \\
\text { (Rp.) }\end{array}$ & $\begin{array}{c}\text { Jumlah } \\
\text { Reponden } \\
\text { (Orang) }\end{array}$ & $\begin{array}{c}\text { Persen } \\
(\%)\end{array}$ \\
\hline 1. $<1.200 .000$ & 4 & 6,45 \\
\hline $\begin{array}{ll}2 . & 1.200 .000- \\
& 3.200 .000\end{array}$ & 12 & 19,35 \\
\hline $\begin{array}{l}3.250 .000- \\
5.250 .000\end{array}$ & 19 & 30,65 \\
\hline 4. $\begin{array}{l}5.300 .000- \\
7.300 .000\end{array}$ & 10 & 16,13 \\
\hline $\begin{array}{ll}\text { 5. } & 7.350 .000- \\
& 9.350 .000\end{array}$ & 5 & 8,06 \\
\hline $\begin{array}{ll} & 9.400 .000- \\
& 11.400 .000\end{array}$ & 3 & 8,84 \\
\hline 7. $>11.400 .000$ & 9 & 14,52 \\
\hline Jumlah & 62 & 100,00 \\
\hline
\end{tabular}

Sumber: Data Hasil Survey

Sebanyak 66,13\% keluarga nelayan berpendapatan antara Rp 1.200.000 sampai Rp 9.350.000. Walaupun demikian, sebanyak 6,45 $\%$ nelayan mempunyai pendapatan keluarga kurang dari Rp 1.200.000 perbulan. Nilai ini akan sangat kecil bila tanggungan keluarga mereka banyak dan masih ada yang sekolah.

Pendapatan total keluarga lebih besar dibandingkan dengan pendapatan utama. Dengan demikian dapat disimpulkan bahwa pendapatan dari pekerjaan sampingan dan pekerjaan isteri berpengaruh dalam meningkatkan pendapatan keluarga nelayan.

\section{Pendapatan Nelayan dan Garis Kemiskinan}

Garis kemiskinan yang dtetapkan oleh Biro Pusat Statistik (BPS) pada tahun 2018 adalah Rp 401.220/kapita /bulan. Pendapatan per kapita di hitung dengan membagi total pendapatan dengan jumlah penduduk.

Pendapatan per kapita di desa Swarangan dihitung berdasarkan pendapatan responden sebagai sampel nelayan dibagi dengan jumlah tanggungan setiap responden. Berdasarkan perhitungan ini, diharapkan dapat menggambarkan secara global kondisi pendapatan di wilayah ini.

Pada Tabel 5 tentang jumlah tanggungan keluarga responden, tergambar bahwa rata-rata jumlah tanggungan keluarga nelayan di desa ini sebanyak 2 (dua) sampai 3 (tiga) orang, walaupun ada yang kurang dan lebih dari itu. Dari Tabel 9 tentang total pendapatan keluarga, lebih hampir $95 \%$ nelayan berpendapatan lebih dari 1.200.000 per bulan, dan secara rata-rata pendapatan mereka Rp 6.762.919 per bulan.

Berdasarkan kedua tabel tersebut, maka pendapatan per kapita nelayan di desa Swarangan masih berada di atas garis kemiskinan. Hanya ada sebagian kecil $(8,06 \%)$ yang perpendapatan kurang dari Rp 500.000 per bulan dan dianggap berada di bawah garis kemiskinan. Tabel 10 memberikan gambaran tentang pendapatan per kapita di wilayah desa Swarangan.

Tabel 10. Pendapatan Per Kapita Keluarga Responden

\begin{tabular}{lccr}
\hline & $\begin{array}{c}\text { Pendapatan } \\
\text { (Rp.) }\end{array}$ & $\begin{array}{c}\text { Jumlah } \\
\text { Reponden } \\
\text { (Orang) }\end{array}$ & \multicolumn{1}{c}{$\begin{array}{c}\text { Persen } \\
(\%)\end{array}$} \\
\hline 1. $\begin{array}{c}<00.000 \\
\text { 2. } 500.000-\end{array}$ & 5 & 8,06 \\
1.500 .000 & 30 & 48,39 \\
3. $\begin{array}{l}1.510 .000- \\
2.510 .000\end{array}$ & 9 & 14,52 \\
4. $\begin{array}{l}2.520 .000- \\
3.520 .000\end{array}$ & 10 & 16,13 \\
5. $\begin{array}{l}3.530 .000- \\
4.530 .000\end{array}$ & 1 & 1,61 \\
6. $\begin{array}{l}4.540 .000- \\
\text { 5.540.000 } \\
\text { 5.540.000 }\end{array}$ & 2 & 3,23 \\
\hline & Jumlah & $\mathbf{6 2}$ & $\mathbf{1 0 0 , 0 0}$ \\
\hline
\end{tabular}

Sumber: Data Hasil Survey

Pada Tabel 10 tersebut terlihat hanya $8,06 \%$ nelayan yang berada di bawah garis kemiskinan, sedangkan sisanya berada di atas garis kemiskinan. Dengan demikian dapat dikatakan, bahwa masyarakat nelayan di wilayah ini termasuk ke dalam kategori penduduk berpendapatan sedang dan tinggi.

Rata-rata pendapatan per kapita mereka adalah Rp 2.204.431 per bulan. Hanya saja, nilai ini masih berada dibawah UMP Kalimantan Selatan tahun 2019 dan 2020, yaitu Rp 2.651.781 dan Rp 2.877.448 perbulan (Pemda Provinsi Kalimantan Selatan dalam Bisnis.com Nopember 2019). Walaupun demikian, pendapatan per kapita ini cukup tinggi dan 
termasuk pada kelompok masyarakat berpendapatan tinggi.

\section{KESIMPULAN DAN SARAN Kesimpulan}

Karakteristik nelayan di desa Swarangan adalah: a) Usia nelayan rata-rata masih berada pada usia produktif dan dapat bekerja dengan baik; b) Rata-rata tingkat pendidikan nelayan adalah SLTP atau yang sederajat; c) Selain sebagai nelayan, mereka mempunyai pekerjaan sampingan dan yang terbanyak adalah bertani, baik sebagai pemilik maupun sebagai buruh tani; d) Tambahan pendapatan nelayan lain adalah dari isteri mereka yang sebagian juga bekerja sebagai pedagang dan lain-lain; e) Tanggungan keluarga nelayan rata-rata antara dua sampai tiga orang, antara lain isteri, anak, atau pun orang tua.

Pendapatan nelayan terdiri dari pendapatan dari hasil melaut (pendapatan utama) dan pendapatan yang ditambah dengan pendapatan isteri dan dari pekerjaan sampingan atau pendapatan total keluarga. Rata-rata pendapatan dari utama/melaut lebih rendah dibandingkan dengan rata-rata pendapatan total keluarga. Pendapatan sampingan dan pendapatan isteri berdampak terhadap peningkatan pendapatan total keluarga.

Pendapatan per kapita nelayan adalah: a) Rata-rata pendapatan per kapita nelayan berdasarkan pendapatan utama atau pendapatan dari hasil melaut saja, yang berada di bawah garis kemiskinan hampir sama dengan yang berada di atas garis kemiskinan; b) Rata-rata pendapatan per kapita nelayan berdasarkan pendapatan total keluarga, yang berada di bawah garis kemiskinan sangat sedikit dibandingkan yang berada di atas garis kemiskinan; c) Baik rata-rata pendapatan utama per kapita maupun rata-rata pendapatan total per kapita, keduanya masih berada di bawah UMP Kalimantan Selatan tahun 2020.

\section{Saran}

Pendidikan nelayan masih rendah, apabila pendidikan formal belum mampu ditingkatkan, maka diharapkan Pemerintah memberikan perhatian untuk menambah pendidikan non formal, seperti penyuluhan dan pelatihan baik untuk meningkatkan hasil tangkapan maupun untuk perbaikan pasca panen hasil laut dengan tujuan untuk meningkatkan pendapatan utama nelayan yang masih rendah.

Nelayan tidak hanya fokus kepada pekerjaan utama dan pekerjaan tambahan selain sebagai nelayan, sebaiknya nelayan mencoba untuk membudidayakan perikanan air tawar sesuai dengan pengalaman sebagai nelayan.
DAFTAR PUSTAKA

Adam Irwansyah Fauzi (2018) Kondisi Nelayan Indonesia: Integrasi Sains dan Teknologi dalam Perspektif Pembangunan di Wilayah Pesisir, Laut, dan Maritim, Magister Teknik Geodesi dan Geomatika, Bandung.

BPS (2019), Garis Kemiskinan Indonesia, bps.go.id, Jakarta.

BPS Kabupaten Tanah Laut (2018), Kecamatan Jorong Dalam Angka 2018, Pelaihari.

Burhan Bungin (2005), Metodologi Penelitian Kuantitatif: Komunikasi, Ekonomi, dan KebijakanPublik Serta Ilmu-Ilmu Sosial Lainnya, Kencana Jakarta.

Dewi Yuliriane (2012), Kontribusi Wisata Bahari Terhadap Pendapatan Rumah Tangga Nelayan di Pantai Pangandaran Kabupaten Ciamis Jawa Barat. Fakultas Perikanan dan Ilmu Kelautan. Skripsi. Universitas Padjadjaran (UNPAD). Jatinangor.

Ferry J. Yulianto dan Aris Munandar (2016) Fenomena Kemiskinan Nelayan: Perspektif Strukturasi, Jurnal Kajian Politik dan Masalah Pembangunan Vol.12, No.02, Jakarta.

Hasyim Ali Imran (2017), Peran Sampling Dan Distribusi Data Dalam Penelitian Komunikasi Pendekatan Kuantitatif, Jurnal Studi Komunikasi Dan Media, Vol.21 No. 1.

Hestanto (2018), Pengertian Pendapatan. Personal

Website.hestanto.web.id/pengertianpendapatan/28 Mei 2018.

Kedeputian Kependudukan dan Ketenagakerjaan (2018), Analisis Wilayah Dengan Kemiskinan Tinggi, Bappenas, 2018

Maulana Firdaus, Tenny Apriliani dan Rizki Aprilian Wijaya (2013), Pengeluaran Rumah Tangag Nelayan Dan Kaitannya Dengan Kemiskinan : Kasus di Desa Ketapang Barat, Kabupaten Sampang, Jawa Timur, Balai Besar Penelitian Sosial Ekonomi Kelautan dan Perikanan, Jakarta.

Tri Wahyu R. (2009) Kemiskinan Dan Bagaimana Memeranginya, Jurnal Ekonomi dan Bisnis, Universitas 
Chandriyanti, I., Fahrati, E.

Diponegoro, Vol.4 No.7, April, Semarang.

Sadono Sukirno (2006), Pengantar Teori Mikro Ekonomi, Rajagrafindo Persada, Jakarta.

Soediyono Reksoprayitno (2009) Ekonomi Makro. Badan Penerbit Fakultas Ekonomi (BPFE): UGM, Yogyakarta.

Sri Wahyuni (2018), Analisis Pendapatan Rumah Tangga Nelayan di Pesisir Kota Agung, Kabupaten Tanggamus, Jurusan
Agribisnis Fakultas Pertanian Universitas Lampung, Bandar Lampung.

T. Gilarso (2008), Pengantar Ilmu Ekonomi Mikro, Kanisius, Yogyakarta.

UU Nomor 7 tahun 2016 tentang Perlindungan dan Pemberdayaan Nelayan, Pembudi Daya Ikan, dan Petambak Garam, Direktorat Jenderal Pengelolaan Ruang Laut, Jakarta, 2019. 